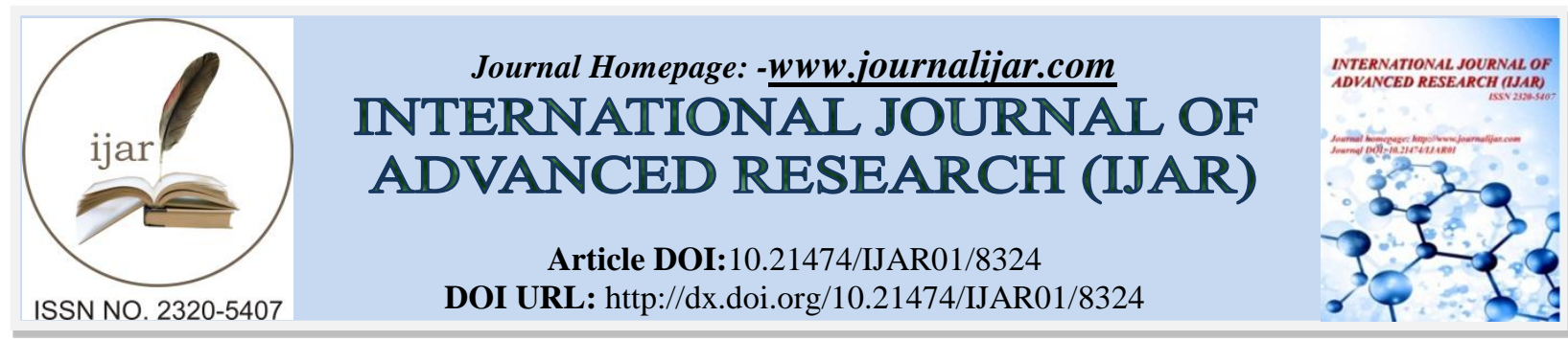

RESEARCH ARTICLE

\title{
THE INFLUENCE OF GOOD GOVERNANCE ON WORK PERFORMANCE OF PERSONNEL OFFICERS OF BANGKOK METROPOLITAN ADMINISTRATION.
}

\author{
Nuntaporn Rattananda ${ }^{1}$, ThuchaponYodthong ${ }^{2}$ and Ornpapha Chutikorntaweesin ${ }^{2}$. \\ 1. Doctoral Candidate, California University FCE, Los Angeles, California, USA. \\ 2. Associate Professor, California University FCE, Los Angeles, California, USA.
}

\section{Manuscript Info}

Manuscript History

Received: 04 November 2018

Final Accepted: 06 December 2018

Published: January 2019

Key words:-

Influence, Good governance,

Work performance, Personnel officers.

\section{Abstract}

The purposes of this research were 1) to study the level of good governance in work performance of personnel officers of Bangkok Metropolitan Administration, 2) to study the characteristics of work performance of personnel officers of Bangkok Metropolitan Administration, 3) to study the relationship between good governance and work performance of personnel officers of Bangkok Metropolitan Administration, and 4) to analyze the influence of good governance on work performance of personnel officers of Bangkok Metropolitan Administration. The researcher applied the quantitative research method. The research results show that the attitude towards good governance practices in total was at high level. In particular, New Public Management had the highest means score, followed by Democratic Value, Administrative Responsibility, and Civil State respectively. The attitude towards work performance of personnel officers of Bangkok Metropolitan Administration in total was at high level. In particular, Job Satisfaction had highest means score, followed by Fully Functional, and Achieving Goals respectively. The components of good governance had a relationship with the components of work performance with the statistical significance at the level of .01. The hypotheses analysis results show that the statistic values to evaluate of the conformance of the model of structural equation after the modification indices consisted of Chi-square Probability Level was .249, CMIN/DF was 1.154 , GFI was .992 , and RMSEA was .015. Therefore, the model of the Influence of good governance on work performance of personnel officers of Bangkok Metropolitan Administration after the modification was relevant to the empirical data at very good level.

Copy Right, IJAR, 2017,. All rights reserved.

\section{Introduction:-}

Nowadays, the situation of politics, economy, and society changes dramatically due to the advance in fast communication and transmission of news and information both between public sector and people sector, and among the people sector. These also led to the materialism in every society in many countries. Therefore, the work performance of personnel officers in public sector, which should mainly focus on benefit of people, may contribute to some groups of people, such as investor who provides the supportive financial factor to the personnel officers in 
public sector who are willing to act for the benefit of their own group. These lead to the corruption that causes damages to the country. The effect of this damage occurred in the past caused the government to use the good governance principles of Office of The Public Sector Development Commission (OPDC) as the guidelines of ethics to be enforced along with the work guidelines of personnel officers in each part. Regarding National Economic and Social Development Plan No. 12 (2017-2021), some objective emphasizes the morality and ethics of people, and the work performance of personnel officers in public sector. The overall goals are to be a complete Thai with discipline, vision and behavior based on good norms of society. In addition, the people sector expected that the public management system will be effective, modern, transparent, verifiable, decentralized, and participatory by people.

The good governance principles of Office of The Public Sector Development Commission (OPDC) consist of 4 main principles, which were new public management, democratic value, participatory state, and administrative responsibility (Office of the Public Sector Development Commission, 2012). These 4 main principles are divided into 10 sub-principles as the guidelines for personnel officers in each sector to apply to suit their work directions.

Bangkok is the capital of Thailand with the most populations and continual development and growth. In each time period, Bangkok has its own development framework which has been always modernized so that this metropolis can develop with its balance and be livable in present time and in the future. The agency responsible to each mission of Bangkok is under the public sector, called by its name 'Bangkok MetropolitanAdministration'. Its duties are divided according to the responsibility to the living of people into the district office in each area. Up till now, the district offices received many complaints from people. Those complaints about various aspects of problems of people are not resolved successfully or in the expected time period. The reasons might be that the problems do not occurred in the area responsible of Bangkok. Importantly, the budget from the original affiliation is not enough for solving problems. The reason about budget causes the doubt on corruption in Bangkok Metropolitan Administration. The current executive of Bangkok Metropolitan Administration recognizes and applies the good governance principles in the administration as the guidelines for public administration. This will lead the organization to the advance and sustainable development in the future.

From these reasons, the researcher was interested in studying about the influence of good governance on work performance of personnel officers of Bangkok Metropolitan Administration. The research results will be the guidelines for executives and personnel relating to the policy setting to improve and develop the work directions to be compatible to the good governance principles. This can lead to the work performance with effectiveness, efficiency, and acceptance from stakeholders inside and outside the organization; this also leads to the achievement of work performance of personnel officers working for other agencies in the future.

\section{Purposes of research:-}

1. To study the level of good governance in work performance of personnel officers of Bangkok Metropolitan Administration.

2. To study the characteristics of work performance of personnel officers of Bangkok Metropolitan Administration.

3. To study the relationship between good governance and work performance of personnel officers of Bangkok Metropolitan Administration.

4. To analyze the influence of good governance on work performance of personnel officers of Bangkok Metropolitan Administration.

\section{Hypotheses of research:-}

$\mathrm{H}_{1}$ New Public Management affects work performance of personnel officers of Bangkok Metropolitan Administration.

$\mathrm{H}_{2}$ Democratic Value affects work performance of personnel officers of Bangkok Metropolitan Administration.

$\mathrm{H}_{3}$ Civil State affects work performance of personnel officers of Bangkok Metropolitan Administration.

$\mathrm{H}_{4}$ Administrative Responsibility affects work performance of personnel officers of Bangkok Metropolitan Administration.

\section{Literature Review:-}

Good governance principles

The good governance principles consist of 4 main principles and 10 sub-principles. The first main principle is new public management, which its sub-principles are efficiency, effectiveness, and responsiveness. The second main 
principle is democratic value, which its sub-principles are accountability, transparency, rule of law, and equity. The third main principle is participatory state, which its sub-principles are participation/consensus oriented, and decentralization. The forth main principle is administrative responsibility, which its sub-principle is morality/ethics (Office of the Public Sector Development Commission, 2012).

\section{Work performance:-}

The work performance is the aspect of result or consequence of the behavior of individuals. In many situations, the behavior gets involved in the result explicitly. In addition, the work atmosphere, leadership, team and relationship among colleagues, job training and job development, rewarding, direction and procedure, and happiness in working of employee, including their participation are important factors affecting work performance of employees. The factors of work performance were; the first is job satisfaction, which means to get the compensation from working that can satisfy that person; the compensation can be either material or mental. This job satisfaction will drive the employees to work willingly with all their ability. The stimulator of job satisfaction is work environment, work procedure, relationship with others in the organization, and compensation; all these have an effect on employees to be enthusiastic and courageous to commit to create their high effective work for the organization to achieve the organizational goals at last. The second is achievement motivation, which means the demand or desire to achieve something as expected, or to have commitment and attempt to conquer the obstacles and problems without discouragement to lead to success and excellent standard. The organization can motivate its employees to work with many methods, such as admiration, acceptance, respect, promotion, salary increase; or the negative motivation, such as punishment and admonishment so that the employees avoid committing mistake. This motivation has a close relationship with socialization that employees received from the old experience from the organization and from environment outside the organization. In case that the executives know how to apply these motivations appropriately to the employees, it will lead the organization to achieve its goals eventually. The practical achievement motivation is in form of fully functional and achieving goal (Anitha, 2014; Khomsan, 2018; Kotler, 1994; Tonekaew, 2010; McClelland, 1965).

\section{Research Methodology:-}

The researcher applied the quantitative research method in conducting this study; studying the secondary data through reviewing the concepts, theories, and related researches from both domestic and international sources. The researcher studied the primary data by distributing questionnaires to 700 samples who are personnel officers at supervisor level in 50 district offices in Bangkok. The sample size and selected the sample by the purposive sampling. The questionnaires were used as the research tool. The statistics used in this study were frequency, percentage, mean, standard deviation, Pearson Correlation, and Path Analysis. This research was conducted from June to October 2018, totaling 5 months.

\section{Research Result:-}

\section{The analysis of demographic profiles:-}

With regard to the demographic profiles, from 700 respondents, the majority of respondents were male, followed by female. Most of respondents are aged 36-45 years, followed by 26-35 years, 46 years and above, and 25 years or lower respectively. Most of respondents graduated the Bachelor Degree, followed by Master Degree. Most of respondents earned 15,001-25,000 Baht per month, followed by 25,001-35,000 Baht, and 35,001-45,000 Baht respectively. Most have worked for 6-10 years, followed by 11-15 years, 16-20 years, and less than 5 years respectively.

The analysis of good governance affecting work performance of personnel officers of Bangkok Metropolitan Administration:-

With regard to the attitude toward good governance affecting work performance, the results show that the attitude in total was at high level $(\overline{\mathrm{x}}=3.86$, S.D. $=0.29)$. In particular, New Public Management had the highest means score $(\overline{\mathrm{X}}=3.95$, S.D. $=0.46)$, followed by Democratic Value $(\overline{\mathrm{X}}=3.84$, S.D. $=0.37)$, Administrative Responsibility $(\overline{\mathrm{X}}=3.83$, S.D. $=0.21)$, and Civil State $(\overline{\mathrm{X}}=3.79$, S.D. $=0.10)$ respectively (see table 1$)$.

Table 1:-Mean and standard deviation of the attitude toward good governance affecting work performance in total

\begin{tabular}{|l|c|c|c|}
\hline \multicolumn{1}{|c|}{ Good governance affecting work performance } & $\overline{\mathrm{X}}$ & S.D. & Translation \\
\hline New Public Management & 3.95 & 0.46 & High \\
\hline Democratic Value & 3.84 & 0.37 & High \\
\hline
\end{tabular}




\begin{tabular}{|c|c|c|c|}
\hline Civil State & 3.79 & 0.10 & High \\
\hline Administrative Responsibility & 3.83 & 0.21 & High \\
\hline Total & $\mathbf{3 . 8 6}$ & $\mathbf{0 . 2 9}$ & High \\
\hline
\end{tabular}

The analysis of work performance of personnel officers of Bangkok Metropolitan Administration:-

With regard to the attitude toward work performance of personnel officers, the results show that the attitude in total was at high level $(\overline{\mathrm{x}}=3.75$, S.D. $=0.35)$. In particular, Job Satisfaction had the highest means score $(\overline{\mathrm{x}}=3.95$, S.D. $=0.55)$, followed by Fully Functional $(\overline{\mathrm{x}}=3.80$, S.D. $=0.45)$, and Achieving Goals $(\overline{\mathrm{x}}=3.61$, S.D. $=0.68)$ respectively (see table 2).

Table 2:-Mean and standard deviation of the attitude toward work performance of personnel officers in total

\begin{tabular}{|l|c|c|c|}
\hline Work performance of personnel officers & $\overline{\mathbf{x}}$ & S.D. & Translation \\
\hline Job Satisfaction & 3.95 & 0.55 & High \\
\hline Fully Functional & 3.80 & 0.45 & High \\
\hline Achieving Goals & 3.61 & 0.68 & High \\
\hline & $\mathbf{3 . 7 5}$ & $\mathbf{0 . 3 5}$ & High \\
\hline
\end{tabular}

The analysis of correlation between the components of good governance and work performance of personnel officers of Bangkok Metropolitan Administration:-

With regard to the correlation, the results show that the components of good governance had a relationship with work performance of personnel officers of Bangkok Metropolitan Administration with the statistical significance at level of .01. The correlation was between .335-.913. The relationship with the highest correlation was the component of good governance in aspect of Morality/Ethics (MOR) and Work Performance (WOR), which was 913. The relationship with the lowest correlation was the component of good governance in aspect of Accountability (ACC) and Work Performance (WOR), which was .335 (see table 3).

Table 3:-Correlation between the components of good governance and work performance of personnel officers of Bangkok Metropolitan Administration

\begin{tabular}{|c|c|c|c|c|c|c|c|c|c|c|c|}
\hline variables & EFI & EFE & REA & ACC & TRA & RUL & EQU & PAR & DEC & MOR & WOR \\
\hline EFI & 1.000 & & & & & & & & & & \\
\hline EFE & $.484^{* *}$ & 1.000 & & & & & & & & & \\
\hline REA & $.552^{* *}$ & $.507^{* * *}$ & 1.000 & & & & & & & & \\
\hline ACC & $.479^{* *}$ & $.358^{* * *}$ & $.460^{* * *}$ & 1.000 & & & & & & & \\
\hline TRA & $.556^{* *}$ & $.425^{* *}$ & $.563^{* *}$ & $.520^{* *}$ & 1.000 & & & & & & \\
\hline RUL & $.356^{* *}$ & $.272^{* *}$ & $.284^{* *}$ & $.211^{* *}$ & $.328^{* *}$ & 1.000 & & & & & \\
\hline EQU & $.584^{* *}$ & $.459^{* *}$ & $.667^{* *}$ & $.451^{* *}$ & $.586^{* *}$ & $.372^{* *}$ & 1.000 & & & & \\
\hline PAR & $.467^{* *}$ & $.340^{* *}$ & $.449^{* *}$ & $.468^{* *}$ & $.488^{* *}$ & $.335^{* *}$ & $.486^{* *}$ & 1.000 & & & \\
\hline DEC & $.441^{* *}$ & $.372^{* *}$ & $.518^{* *}$ & $.396^{* *}$ & $.497^{* *}$ & $.328^{* *}$ & $.496^{* *}$ & $.455^{* *}$ & 1.000 & & \\
\hline MOR & $.467^{* *}$ & $.406^{* *}$ & $.513^{* *}$ & $.321^{* *}$ & $.420^{* *}$ & $.335^{* *}$ & $.549^{* *}$ & $.515^{* *}$ & $.610^{* * *}$ & 1.000 & \\
\hline WOR & $.442^{* *}$ & $.478^{* *}$ & $.511^{* *}$ & $.335^{* *}$ & $.387^{* *}$ & $.539^{* *}$ & $.519^{* *}$ & $.515^{* *}$ & $.559^{* *}$ & $.913^{* *}$ & 1.000 \\
\hline
\end{tabular}

$* *$ the statistical significance at level of .01

The analysis of the model of the influence of good governance on work performance of personnel officers of Bangkok Metropolitan Administration with the empirical data:-

With regard to the model of influence, the results show that the statistic values to evaluatethe conformance of the model of structural equation after the modification indices consisted of Chi-square Probability Level $=.249$, $\mathrm{CMIN} / \mathrm{DF}=1.154, \mathrm{GFI}=.992$, and RMSEA $=.015$. Therefore, the model of the influence of good governance on work performance of personnel officers of Bangkok Metropolitan Administration after the modification was relevant to the empirical data at very good level (see figure 1). 


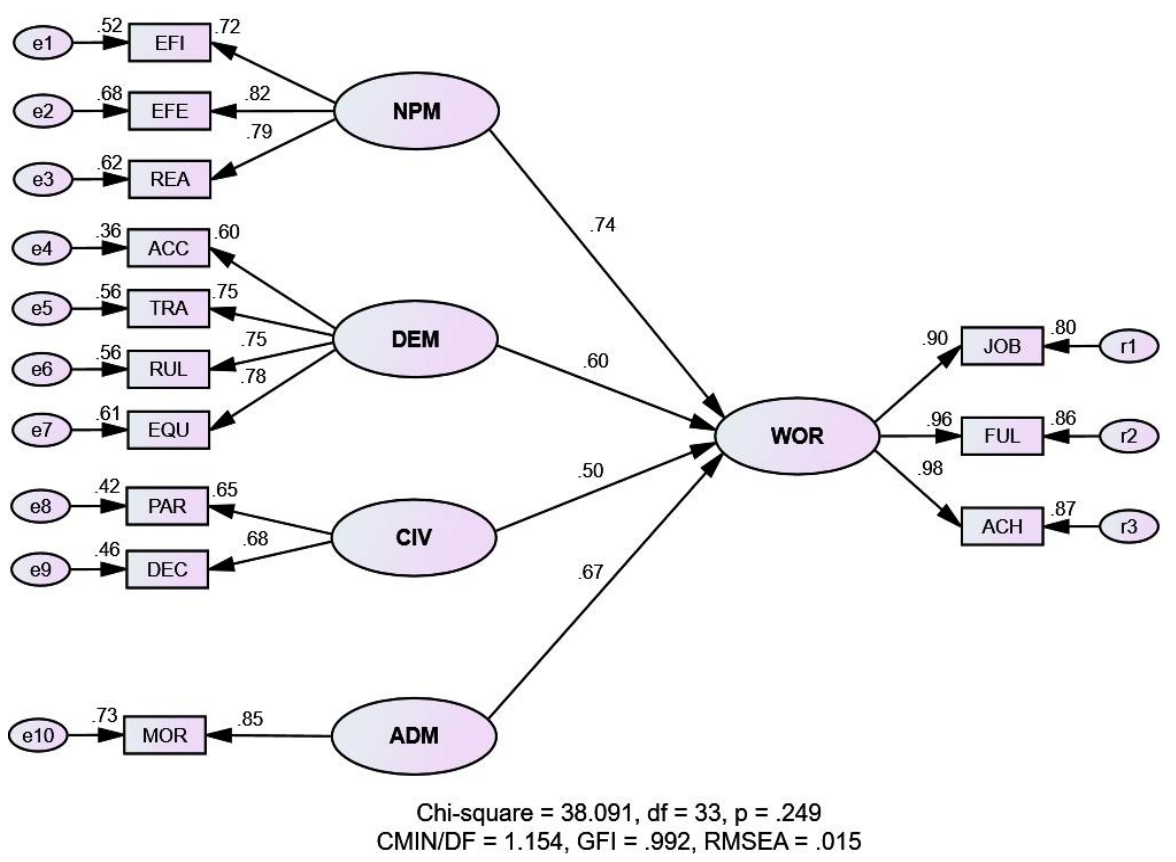

Figure 1:-The model of the influence of good governance on work performance of personnel officers of Bangkok Metropolitan Administration.

The hypotheses results show that:-

$\mathrm{H}_{1}$ : New Public Management affects work performance of personnel officers of Bangkok Metropolitan Administration.

The result shows that New Public Management affected work performance of personnel officers of Bangkok Metropolitan Administration with the statistical significance at level of .01, which is relevant to the set hypothesis.

$\mathrm{H}_{2}$ : Democratic Value affects work performance of personnel officers of Bangkok Metropolitan Administration. The result shows that Democratic Value affected work performance of personnel officers of Bangkok Metropolitan Administration with the statistical significance at level of .01, which is relevant to the set hypothesis.

$\mathrm{H}_{3}$ : Civil State affects work performance of personnel officers of Bangkok Metropolitan Administration.

The result shows that Civil State affected work performance of personnel officers of Bangkok Metropolitan Administration with the statistical significance at level of .01, which is relevant to the set hypothesis.

$\mathrm{H}_{4}$ : Administrative Responsibility affects work performance of personnel officers of Bangkok Metropolitan Administration.

The result shows that Administrative Responsibility affected work performance of personnel officers of Bangkok Metropolitan Administration with the statistical significance at level of .01, which is relevant to the set hypothesis.

\section{Discussion:-}

Regarding the good governance affecting work performance of personnel officers of Bangkok Metropolitan Administration, the components with the highest mean score is new public management, followed by democratic value, administrative responsibility, and civil state respectively. This is relevant to the study of Phansanit (2014) that the local government in Nakhonratchasima Province used the good governance principles to set the policy in every aspects, which were transparency, efficiency, effectiveness, accountability, rule of law responsiveness, participation/ consensus oriented, and decentralization in higher level, with two exceptions of morality/ethic, and equity, which in turn score very high. The factors in correlation with the operation in accordance with good governance principles of the provincial governance in Nakhonratchasima Province consist of factors on executive's leadership, factors on official governor's attitude, factors on procuring, supporting, controlling, evaluating, and providing benefit and harmful to personnel as well as the factors on outer organization environment. In addition, this is relevant to the 
study of Khalid, Alam, and Said (2016) that the public sector must be transformed into a reliable and efficient sector by ensuring good governance and implementing a proper assessment system. Enhancement of good governance practices can help achieve the aspirations of stakeholders and ensure accountability of the public sector. Departments and ministries should also exhibit ethics and integrity in activities they organize to cultivate good governance in order to educate thepublic. This is also relevant to the study of Jhantasana (2016) that good governance is positively related to job satisfaction; job satisfaction is positively related to organizational commitment; and the perceived organizational support is positively related to organizational citizenship behavior.

Moreover, the results also show that new public management had an effect on work performance of personnel officers of Bangkok Metropolitan Administration. This is relevant to the study of De Vries \& Nemec (2013) that many new public management based tools and instruments are still used and optimized in order to support process improvements. Internally governments are still trying to optimize their internal workings. They do this by many different patterns, at least partly diverging from of the ideas of new public management. To sum up, a shift is indeed visible from emphasizing minimal government (new public management) into a trend towards good governance. This is also relevant to the study of Rod \& Ashill (2010) that frontline-employee customer orientation has a direct beneficial effect for both job satisfaction and organizational commitment but with the impact being significantly stronger on job satisfaction. Frontline-employees who exhibit higher levels of customer orientation respond more favorably to the job and the organization than those who have lower levels of customer orientation. In this research, personnel officers of Bangkok Metropolitan Administration prioritized effectiveness the most. In addition, this is relevant to the study of Klongkayan, Chumpoo, and Chaisriha (2017) that the new public management of Municipality in Phetchabun Province as overall was at moderated level; and it had a positive relationship in moderate level with the performance competency, the organization engagement, and the learning organization. Additionally, this is relevant to the study of Kositanont (2016) that the factors affecting human resource development of local administrative organizations based on the new public management were the procedure elimination in working performance, the government systematic development factor, the government working performance evaluation factor, the policy specification factor, and the administrational factor.

The results also show that democratic value had an effect on work performance of personnel officers of Bangkok Metropolitan Administration. This is relevant to the study of Vivian Chen, Yuan, Cheng, \& Seifert (2016) that in practice, proponents of accountability mechanisms posit that their behavioral impacts are essential for controlling the performance levels of organizations and their members. Regarding the positive relationship and the direct relationship between felt accountability and job performance, the manager can create work environment directly for the benefit of the subordinates. Accordingly, the improvement of attitude about felt accountability and job performance achievement will be in higher level. This is also relevant to the study of Manafe\& Akbar (2014) that the work performance of the accountability actors is negatively correlated to the work pressure, while the workload can increase the work performance of the accountability actors. This means the workload had an effect on work performance of actors. According to the study of Palanski, Kahai, \&Yammarino (2011), team transparency had a positive relationship with team behavioral integrity. It is the exchange of important data toward behavioral integrity. It is also found the relationship between team behavioral integrity and team trust; which means the trust played an important role in directing the work of team. The study of Kim \& Lee (2010) also demonstrated that an emphasis on compliance accountability over professional and political accountability could have negative impacts on accomplishing agency missions by increasing employees' perceived workload and job tension. In addition, this is relevant to the study of Laoratsameewiwat (2009) that factors of work stress, factors of justice, and factors of organization commitment correlated to employees' total job satisfaction at Provincial Electricity Authority North 3 (North region) at 0.01 statistically significant level, at moderate level in same direction.

The results also show that civil state had an effect on work performance of personnel officers of Bangkok Metropolitan Administration. This is relevant to the study of Cho \& Kim (2014) that the participative management practices was one methods to develop the effectiveness of public management, starting from the adoption of new public management principles. The self-managing work team will lead to improvement in performance. Therefore, the organization in public sector should consider using the participative management practices to develop the work performance. This is also relevant to the study of Wisut (2014) that the attitude toward participation, good governance administration and performance were at high level. The hypothesis results show that participation had an influence on good governance the most, followed by on performance. The administration had an influence on good governance the most, followed by performance. The good governance had an influence on performance the most. Additionally, this is relevant to the study of Saweangphon (2011) that the capability had affected toward 
the job performance at the highest level, followed by job scope understanding had affected toward the job performance, and the participation had affected toward the job performance the least. In addition, this is relevant to the study of Sookdee (2011) that the participation in budgeting process had a high relationship with the overall operation success, which means participation had a positive influence on the institutional operation in compliance with the budgeting process of the university.

The results also show that administrative responsibility had an effect on work performance of personnel officers of Bangkok Metropolitan Administration. This is relevant to the study ofDemir, Reddick, Ponomariov, \& Flink (2018) that there were positive relationship between power and accountability, power and performance, and accountability and performance. For the level of professionalism of the executives, a free society should be cognizant of what substantive areas are affected by increase or decrease in bureaucratic power, and this awareness is possible to maintain only by looking beyond abstract justifications for reform such as "efficiency" and "accountability." This is also relevant to the study of Hwang (2013) that accountability and performance may be similar in terms of responsibility, serving children and community, following policy and guidelines, completing tasks, and ethics. Accountability affects performance directly and indirectly in a varied way, and accountability management matters in the relationship between accountability and performance. The accountability of ethics and law had a direct influence on the child welfare service effectiveness in a positive way. The study of Jain (2016) also presented that the assignment of administrative responsibility had a relationship with the effective time utilization with the statistical significance which contributed to the overall development of organizational personnel. According to the study of Meemak (2018), the environment factor and the input factor had a positive influence on the work efficiency on internal audit in quite high level with the statistical significance at level of 0.01 . The loyalty and ethics had a positive relationship with work efficiency, and also had both direct and indirect impact through the functional competency toward the work efficiency on internal audit. In addition, this is relevant to the study of Panyindee (2015) that the causal relationship model between the ethical organization and the organizational citizenship behavior on academic performance of Rajabhat University lecturer was congruent with the empirical data. The ethical organization had direct effect on the academic performance and indirect effect through the organizational citizenship behavior. Moreover, the ethical organization had direct effect on the organizational citizenship behavior and the organizational citizenship behavior had direct effect on the academic performance.

Regarding the research results and discussion, every main factor of good governance principles had an influence on work performance of personnel officers of Bangkok Metropolitan Administration. The results of every main principle and sub-principle had an influence on work performance of personnel officers of Bangkok Metropolitan Administration in the positive way at high level. The main factor affecting work performance of personnel officers of Bangkok Metropolitan Administration at the first rank was new public management, followed by administrative responsibility, democratic value and civil state respectively. The results of this research are relevant to those of other researches, both in Thailand and in foreign countries. This can confirm that good governance had an effect on work performance of personnel officers of Bangkok Metropolitan Administration. Therefore, the executives of agencies under Bangkok Metropolitan Administration at every level should recognize and support the application of good governance as the guidelines along with the specialized operations of each agency. In addition, each agency should be supported to operate their work in the same direction in order to generate the development of agency in public sector at every level to lead to the sustainable development of the country in the future.

\section{Recommendations:-}

Recommendations for this research:New Public Management:-

1. The district offices in Bangkok should reduce the unnecessary expenses, process, and time in working; cancel the obsolete and unnecessary activities or missions; and use the government equipment worthily.

2. The district offices in Bangkok should systematically work with good standard; set the explicit work goals; perform duties according to the mission; and have strategic vision.

3. The district offices in Bangkok should respond to the expectation or demand of stakeholders; create trust and reliability; provide good-quality service within the specified time period.

\section{Democratic Value:-}

1. The district offices in Bangkok should be able to answer the questions and clarify when in doubt; set a system for reporting progress and achievement to the public; allow stakeholders to check their work; and set a system to correct or alleviate problems that may arise from government operations. 
2. The district offices in Bangkok should perform the government operations with loyalty and straightforwardness; set a modern system to monitor the progress of services; disclose the necessary and reliable information to stakeholders; and set a communication system that is easily accessible.

3. The district offices in Bangkok shouldenforce the law and regulations strictlyfairly; apply the technology in providing service; recognize the equality ofthe disadvantaged to access the public services; and provide services according to queue order.

\section{Civil State:-}

1. The district offices in Bangkok should listen to opinion of people; allow people to express their opinion in the process of problem solving; and allow those who disagree to express opinions and find a peaceful solution.

2. The district offices in Bangkok should decentralize the responsibility for decision making to personnel officers in each level appropriately; provide opportunity to personnel officers in each level to fully perform their duties; and delegate authority to various levels of workers appropriately.

\section{Administrative Responsibility:-}

1. The district offices in Bangkok should work with the focus on its results; rely on democracy, be responsible and dare to stand for the right thing; and mainly take into account the benefit and happiness of people.

\section{Recommendations for future research:-}

1. There should be additional study and define the additional variables in addition to Job Satisfaction, Fully Functional, and Achieving Goals in order to develop the work performance of personnel officers.

2. There should be qualitative research so that quantitative and qualitative research results can be applied in other area with the special local government as Bangkok, such as Pattaya.

3. The research area should be expanded, for example, central administration or regional government, to know the similarity and difference of the research results from different areas and populations

\section{References:-}

1. Anitha, J. (2014). Determinants of employee engagement and their impact on employee performance. International Journal of Productivity and Performance Management, 63(3), 308-323.

2. Cho, T. \& Kim, C. (2014). Participative management practices for improving performance in public sector organisations: Mediating roles of performance feedback. International review of public administration. 13(3), 35-51.

3. Demir, T., Reddick, C. G., Ponomariov, B., \& Flink, C. M. (2018). Does Power Corrupt? An Empirical Study of Power, Accountability, and Performance Triangle in Public Administration. International Journal of Public Administration, 1-18.

4. De Vries, M., \& Nemec, J. (2013). Public sector reform: an overview of recent literature and research on NPM and alternative paths. International Journal of Public Sector Management, 26(1), 4-16.

5. Hwang, K. (2013). Impact of Accountability and Accountability Management on Performance at the Street Level. $\mathrm{PhD}$ Thesis. Virginia Polytechnic Institute and State University.

6. Jain, J. (2016). Study of the Impact of Employee Job Satisfaction on Effective Time Utilization in Higher Education. PhD Thesis. Research Centre International Institute of Professional Studies Devi Ahilya Vishwavidyalaya Indore, (MP).

7. Jhantasana, C. (2016). The effect of good governance to organizational citizenship behavior of Rajabhat University employee. Journal of Thonburi University, 10(21), 92-104.

8. Khalid, M. A., Alam, Md. M., and Said, J. (2016). Empirical assessment of good governance in the public sector of Malaysia. Economics and Sociology, 9(4), 289-304.

9. Khomsan, O. (2018). Job satisfaction of employees of Siam City Bank Public Company Limited in Surat Thani Province. Term Report of Master of Business Administration, SuratthaniRajabhat University.

10. Kim, S. E., \& Lee, J. W. (2010). Impact of competing accountability requirements on perceived work performance. American Review of Public Administration, 40, 100-118.

11. Klongkayan, S., Chumpoo, S, and Chaisriha, P. (2017). Relationship between New Public Management and Human Resource Development of Municipality in Phetchabun Province. In Proceedings of the $2^{\text {nd }}$ Graduate Research Conference of Mahasarakham Rajabhat University 2017. Mahasarakham: Mahasarakham Rajabhat University. 
12. Kositanont, V. (2016). Human Resource Development of Local Administrative Organizations under the New Public Section Management. Dissertation of Doctoral of Public Administration Phetchabun Rajabhat University.

13. Kotler, P. (1994). Marketing Management: Analysis Planning Implementation and Control ( ${ }^{\text {th }}$ ed.). Englewood cliffs: Prentice Hall.

14. Laoratsameewiwat, R. (2009). Factors relating employees' Job Satisfaction in Provincial Electricity Authority North 3 (North region). Master's Project, M.B.A. (Management) Srinakharinwirot University.

15. Manafe, M. W. N., \& Akbar, R. (2014). Accountability and Performance: Evidence from Local Government. Journal of Indonesian Economy and Business, 29 (1), 56-73.

16. McCleland, D. C. (1965). Toward a Theory of Motive Acquisition. American Psychologist, 20, 321 -333.

17. Meemak, T. (2018). Factors that affect the work efficiency of internal audit of private higher education institutions in Thailand. Journal of Suvarnabhumi Institute of Technology (Humanities and Social Sciences), 4(1), 24-39.

18. Office of the Bangkok Civil Service Commission. (2018). The rate of ordinary government officials of Bangkok and teacher and educational personnel of Bangkok. Retrieve from http://www.bangkok.go.th.

19. Office of the Public Sector Development Commission. (2012). Good Governance Princi-ples. Retrieve from https://www.opdc.go.th/content.php?menu_id=5\&content_id=2442

20. Palanski, M., Kahai, S., \& Yammarino, F. (2011). Team virtues and performance: An examination of transparency, behavioral integrity, and trust. Journal of Business Ethics, 99, 201-216.

21. Panyindee, J. (2015). The Causal Relationship Model between Ethical Organization and Organizational Citizenship Behavior on Academic Performance of Rajabhat University Lecturer. Thesis of Doctor of Philosophy Program in Management, Silpakorn University.

22. Phansanit, A. (2014). Implementation of good governance principles of provincial administration in Nakhon Ratchasima Province. Journal of politics, administration and law, 6(3), 335-358.

23. Rod, M., \& Ashill, N. J. (2010). The effect of customer orientation on frontline employees job outcomes in a new public management context. Marketing Intelligence \& Planning, 28(5), 600-624.

24. Saweangphon, P. (2011). The Affect of Participation, Administration, Job Scope Understanding and Capability toward the Job Performance of Denchai Tobacco Factory. Thesis of Master of Business Administration, Lampang Rajabhat University.

25. Sookdee, N. (2013). A Study of Influence of Knowledge and Attitude on the Success of Work Performance through Participation of Budgeting Process on Kanchanaburi Rajabhat University. Thesis of Master of Arts Program of Public and Private Management, Silapakorn University.

26. Tonekaew, P. (2010). Factors affecting the achievement motivation of students in production technique in Level 2 of vocational certificate in educational institutions under the Vocational Institute of Northeastern Region 5. Thesis of Master of Industrial Education, King Mongkut's University of Technology Thonburi.

27. Vivian Chen, C.-H., Yuan, M.-L., Cheng, J.-W., \& Seifert, R. (2016). Linking transformational leadership and core self-evaluation to job performance: The mediating role of felt accountability. The North American Journal of Economics and Finance, 35, 234-246.

28. Wisut, P. (2014). Effect of Participation and Good Governance Administration toward Performance Capability of Business Leasing Personnel at Muang District, Lampang Province. Thesis of Master of Business Administration, Lampang Rajabhat University. 